\title{
The effect of de-icing roads with salt on the environment in Krakow (Poland)
}

\author{
Anna Kostka ${ }^{1}$, Magdalena Strzebońska ${ }^{2}$, Maciej Sobczyk ${ }^{3}$, Marta Zakrzewska ${ }^{4}$, \\ Anna Bochenek ${ }^{5}$ \\ ${ }^{1}$ AGH University of Science and Technology, Faculty of Geology, Geophysics and Environmental Protection, \\ Department of Environmental Protection; al. A. Mickiewicza 30, 30-059 Krakow, Poland; \\ e-mail: kostka@agh.edu.pl; ORCID ID: 0000-0003-2062-6476 \\ ${ }^{2}$ AGH University of Science and Technology, Faculty of Geology, Geophysics and Environmental Protection, \\ Department of Environmental Protection; al. A. Mickiewicza 30, 30-059 Krakow, Poland; \\ e-mail: mstrzebo@agh.edu.pl; ORCIDID: 0000-0003-2224-6346 \\ ${ }^{3}$ e-mail:macieksobczykswim@gmail.com \\ ${ }^{4}$ e-mail:nowakm322@gmail.com \\ ${ }^{5}$ e-mail:ania.lapka@onet.eu
}

(C) 2019 Authors. This is an open access publication, which can be used, distributed and reproduced in any medium according to the Creative Commons CC-BY 4.0 License requiring that the original work has been properly cited.

Received: 30 April 2019; accepted: 12 September 2019; first published online: 7 October 2019

\begin{abstract}
The de-icing of roads and streets in the winter season is a necessity in many European countries, where the mean day temperature drops below $0^{\circ} \mathrm{C}$ for long periods. Among the many chemicals used for winter road maintenance, the most popular in Poland is sodium chloride in various forms and mixtures, due to its relatively low price and availability. This agent, however, contributes to the increase of salinity in the soil environment and may lead to disturbances in soil properties and premature plant necrosis. The impact of the usage of chloride salts on the soil environment was researched in Krakow's city centre by means of the examination of soil samples collected prior to the de-icing season (November) and afterwards (February) as well as snow samples taken in February. A general deterioration of the examined parameters $(\mathrm{pH}$, conductivity, chloride concentrations, carbonate concentrations) was observed after the winter season, but still the results for most samples did not pose a serious threat to the soil environment or plants. This was mainly the result of the fact that the winter seasons in European countries have become increasingly mild and warm, which contributes to decreased usage of chloride salts. However, the state of soils in the Main Square was disturbing, as demonstrated by the clearly elevated chemical parameters of samples, despite a ban on the use of salt in this area. These results indicate the most probable reason for the withering of trees growing there, leading to them being frequently replaced.
\end{abstract}

Keywords: Krakow, soil salinity, road salt, winter road maintenance

\section{INTRODUCTION}

The intensive development of cities and road transport in the $20^{\text {th }}$ century necessitated the introduction of road de-icing measures in order to maintain appropriate safety standards. This applies to many European and North America countries, where the average daily temperature in the winter season drops below $0^{\circ} \mathrm{C}$ (Norrman 2000). The beginnings of the use of de-icing agents and abrasive materials (such as sand) in various countries, dates to the 1940s, while it took 30 years for the popularization of this method (Kelly et al. 2008). Snow and ice can be removed from roads mechanically or chemically. In North-Eastern European countries, the second method is mainly used for economic reasons, and the most frequently used agents are inorganic chemicals represented by: 
$\mathrm{NaCl}, \mathrm{CaCl}_{2}, \mathrm{MgCl}_{2}$, brine $\left(\mathrm{NaCl}\right.$ or $\mathrm{CaCl}_{2}$ solution of $20-25 \%$ concentration), hydrated salt (consisting of $30 \%$ brine and $70 \% \mathrm{NaCl}$ ), road salt (approx. $97 \% \mathrm{NaCl}$, approx. $2.5 \% \mathrm{CaCl}_{2}$ and approx. $\left.0.2 \% \mathrm{~K}_{4}\left[\mathrm{Fe}(\mathrm{CN})_{6}\right]\right)$ and various mixtures of $\mathrm{NaCl}$, $\mathrm{CaCl}_{2}$ and $\mathrm{MgCl}_{2}$. Their purpose is to lower the water solidification (freezing) temperature. Road salt is commonly used in North-Eastern Europe, although it is banned in many countries of the European Union. The following organic agents are also used: calcium acetate $\mathrm{Ca}\left(\mathrm{CH}_{3} \mathrm{COO}\right)_{2}$, magnesium acetate $\mathrm{Mg}\left(\mathrm{CH}_{3} \mathrm{COO}\right)_{2}$, potassium acetate $\mathrm{CH}_{3} \mathrm{COOK}$, potassium formate $\mathrm{HCOOK}$, urea $\mathrm{H}_{2} \mathrm{NCONH}_{2}$, alcohols $\mathrm{C}_{\mathrm{n}} \mathrm{H}_{2 \mathrm{n}+1} \mathrm{OH}$ and by-products from sugar beet and corn processing (Turunen 1997, Kołodziejczyk \& Ćwiąkała 2009).

The use of the above mentioned chemicals results in the elevated salinity of soils and waters, where salinity is defined as the accumulation of salt ions: potassium $\left(\mathrm{K}^{+}\right)$, magnesium $\left(\mathrm{Mg}^{2+}\right)$, calcium $\left(\mathrm{Ca}^{2+}\right)$, sodium $\left(\mathrm{Na}^{+}\right)$, chlorides $\left(\mathrm{Cl}^{-}\right)$, sulphates $\left(\mathrm{SO}_{4}^{2-}\right)$, carbonates $\left(\mathrm{CO}_{3}^{2-}\right)$, bicarbonates $\left(\mathrm{HCO}_{3}^{-}\right)$and nitrates $\left(\mathrm{NO}_{3}^{-}\right)$(Provin \& Pitt 2019), and the anthropogenic pollution is mainly associated with chloride and sodium ions (Löfgren 2001, Siyal et al. 2002, Thunqvist 2004, Kelting et al. 2012, Perera et al. 2013, Dailey et al. 2014). Periodical salinity elevation occurs in winter and in early spring, followed by dissolution of salt and its leaching deep into the soil profile. Winter-applied $\mathrm{NaCl}$ is flashed-out over time, however this process is not as rapid as was previously thought. The salt remains in the subsurface layers of soil for several months after application and in its deeper layers for the entire year. Moreover, high salt concentrations may even appear during summer vegetation bloom and the consequences of historical $\mathrm{NaCl}$ application may be long-term due to salt retention (Siyal et al. 2002, Godwin et al. 2003, Černohlávková et al. 2008, Kelly et al. 2008, Findlay \& Kelly 2011). This duration depends on many factors, and one of the most important is the amount of precipitation. It was shown that the content of salt measured in the branches of trees that grow along the streets on which salt was used depends on the temperature and amount of precipitation (Lumis et al. 1976).

The salinity of soil changes its properties. $\mathrm{NaCl}$ reduces water circulation in the soil and changes the air ratios, thus reducing the ground permeability and aeration, affects structure of soil aggregates, humidity, buffering capacity or $\mathrm{pH}$ (Ramarkishana \& Viraraghavatan 2005, Ćwiąkała et al. 2012, Provin \& Pitt 2019). During evaporation, salts remain in the soil, whereas excessive salinity causes sodium to displace other cations, including hydrogen ions, which contributes to soil alkalization. This, in turn, causes the minerals to transform into less soluble or insoluble forms and they become inassimilable for plants. The negative impact of salt on plants is also caused by the reduced availability of water (physiological drought). Additionally, there is the disturbance of the ionic balance - an excessive amount of $\mathrm{Na}^{+}$and $\mathrm{Cl}^{-}$prevents the absorption of other ions, such as: $\mathrm{Ca}^{2+}$, $\mathrm{K}^{+}, \mathrm{Mg}^{2+}, \mathrm{NO}_{3}^{-}$(Munns \& Termaat 1986, Francois \& Maas 1999, Munck et al. 2010, Findlay \& Kelly 2011). $\mathrm{NaCl}$ is also known to derange nitrogen $\mathrm{cy}-$ cling (Green \& Cresser 2008, Green et al. 2008). Finally, the physiological and metabolic processes in the plants are disturbed, for example, photosynthesis efficiency is reduced, productivity of plant biomass is decreased, necrotic changes and premature shedding of leaves may appear, leading finally to plants dieback. Younger plants are considered to be less tolerant of salinity due to their shallower roots. Elevated salinity also has a negative impact on microorganisms, additionally disturbing the soil environment (Czerniawska-Kusza et al. 2004, Yuan et al. 2007, Černohlávková et al. 2008, Hofman et al. 2012).

In addition to chlorides, accompanying pollutants are also emitted to the environment. Chlorides are characterized by strong hygroscopicity, thus additional agents that prevent clumping of salt lumps, the so-called anti-caking agents, are necessary. Most often these are ferrocyanides, and their degradation releases the toxic cyanide ion $\mathrm{CN}^{-}$(Novotny et al. 1998, Kelly et al. 2008, 2010). Apart from that, the soil is also polluted with heavy metals and other substances accompanying de-icing agents, which penetrate the soil and ultimately pollute the water and soil environment (Novotny et al. 1998, Bäckström et al. 2004, Adamiec et al. 2013) and elevated salinity can additionally lead to the release of previously adsorbed heavy metals and enhance their transport to surrounding area (Findlay \& Kelly 2011). 
The aim of the study was to assess the impact of road de-icing agents on the soil environment in Krakow, especially in the area of the historic city centre.

\section{STUDY AREA AND METHODS}

Krakow is a city situated in the south of Poland, at the foot of the Carpathian Mountains, at the meeting point between the Kraków-Częstochowa Upland (also called Polish Jurassic Highland, Polish Jura or Jurassic Rock Upland), Carpathian Foothills and the Sandomierz Basin. The medieval city centre and Wawel Castle were added to the UNESCO World Heritage List in 1978. Roads are arranged around the city centre more or less in a concentric manner, forming so-called ringways.

In order to determine the impact of the sprinkling of roads with sodium chloride on the soil environment in Krakow, soil samples were taken from two areas in the city, located within the borders of the first and second ringway respectively. In addition, snow samples were taken from the area situated beyond the second ringway (Fig. 1). De-icing of roads and streets in the area of Krakow which have been previously cleared of snow, located outside the first ringway, is carried out with the use of brine and hydrated salt (at the temperature up to $-10^{\circ} \mathrm{C}$ ) or a mixture of agents mentioned above, with sand (at the temperature below $-10^{\circ} \mathrm{C}$ ). Pavements, footbridges, cycle pathways etc., must be cleared of snow and sprinkled with sand. The use of de-icing chemicals considered to be environmentally friendly, like calcium chloride or magnesium chloride, is permissible, and in some special cases also a mixture of abrasive material with road salt is acceptable. Streets and pavement within the first ringway may be treated only with sand, and the use of chemical agents is generally strictly forbidden. In special cases, and only for some specified areas, calcium chloride may be applied.

Ten samples (1A-5A and $1 \mathrm{~B}-5 \mathrm{~B})$ were collected within the area of the first ringway surrounding the Old Town (where traffic is restricted), in five locations. Samples 1-4 were taken from the Planty Gardens area (a green belt surrounding the inner city centre with an area of about $20 \mathrm{ha}$ ): A - in the distance of approx. $1 \mathrm{~m}$ from the road edge and
B - approx. $25 \mathrm{~m}$ from the edge. Samples 5 (A, B) were taken from the Main Square, where pursuant to the regulations of Krakow City President, the use of any chemical agents is strictly forbidden. The samples were taken before (November) and after (February) the winter season.

Within the area of the second ringway, samples were collected from the green belt of the width of approx. $20 \mathrm{~m}$, situated between the lanes of a very busy artery, the Trzech Wieszczów Avenue, which constitutes a part of the ringway. This is an area which experiences very heavy traffic - approx. 5,000 vehicles/h according to data provided by the Krakow City Roads Administration (ZDMK) (until recently called ZIKiT - the Municipal Infrastructure and Transport Administration). These roads have to be maintained in a passable condition at all times (to the first national standard for winter maintenance), which means that up to two hours after the end of precipitation, the road must be cleared of snow and sprinkled with de-icing chemicals (Dz.U. $2005 \mathrm{nr}$ 230, poz. 1960). 10 samples $(6 \mathrm{~A}-10 \mathrm{~A}$ and $6 \mathrm{~B}-10 \mathrm{~B})$ were collected from the area of the Trzech Wieszczów Avenue in November and February, from 5 measuring points spaced approx. 300 m apart (Fig. 1). Samples 6 (A, B) were collected at a distance of $5 \mathrm{~m}$ from the road edge, and samples $7 \mathrm{~A}-10 \mathrm{~A}$ and $7 \mathrm{~B}-10 \mathrm{~B}$ were collected at a distance of $1 \mathrm{~m}$ from the road edge.

Moreover, seven snow samples were also taken from the area along the Czarnowiejska Street (1117) and one sample (18) was taken from the Main Square. Snow samples were collected in February.

The geochemical studies included the analysis of selected physical and chemical parameters in the collected soil and snow samples.

The soil samples were taken regarding ISO 18400-104:2018 guidelines, with the use of a manual soil sampling probe, enabling to take ground material up to the depth of $20 \mathrm{~cm}$. At each sampling point, soil was taken from the corners and intersection of diagonals of $1 \mathrm{~m}$-side square, then material was placed into a plastic bag and mixed, obtaining one representative sample. During laboratory treatment, the soil material was cleared of any mechanical impurities and prepared for further analyses (drying, crushing, sieving, dividing and grinding) in accordance with ISO 23909:2008 and ISO 11464:2006 standards. A 1: $5(\mathrm{~m} / \mathrm{v})$ water 
extract was prepared in a proportion of one part soil with the grain size of $<2 \mathrm{~mm}$ : five parts of deionized water. The sample was shaken for 30 minutes, and then the solution was centrifuged and the water content seeped off.

The following parameters were defined for the soil extract and the snow samples: (1) pH values measurement on the basis of standard ISO 10390:2005; (2) specific electrical conductivity measurement in accordance with standard ISO 11265:1994; (3) content of chlorides determined with the use of Mohr's method according to standard ISO 9297:1989. This method involves direct titration of the neutral chloride solution with a standard $\mathrm{AgNO}_{3}$ solution in the presence of $\mathrm{K}_{2} \mathrm{CrO}_{4}$ as an indicator. Moreover, the content of carbonates in soils was defined using the volumetric method according to standard ISO 10693:1995. This method involves the decomposition of carbonates present in the soil using hydrochloric acid and the measurement of the emitted carbon dioxide with a Scheibler apparatus.
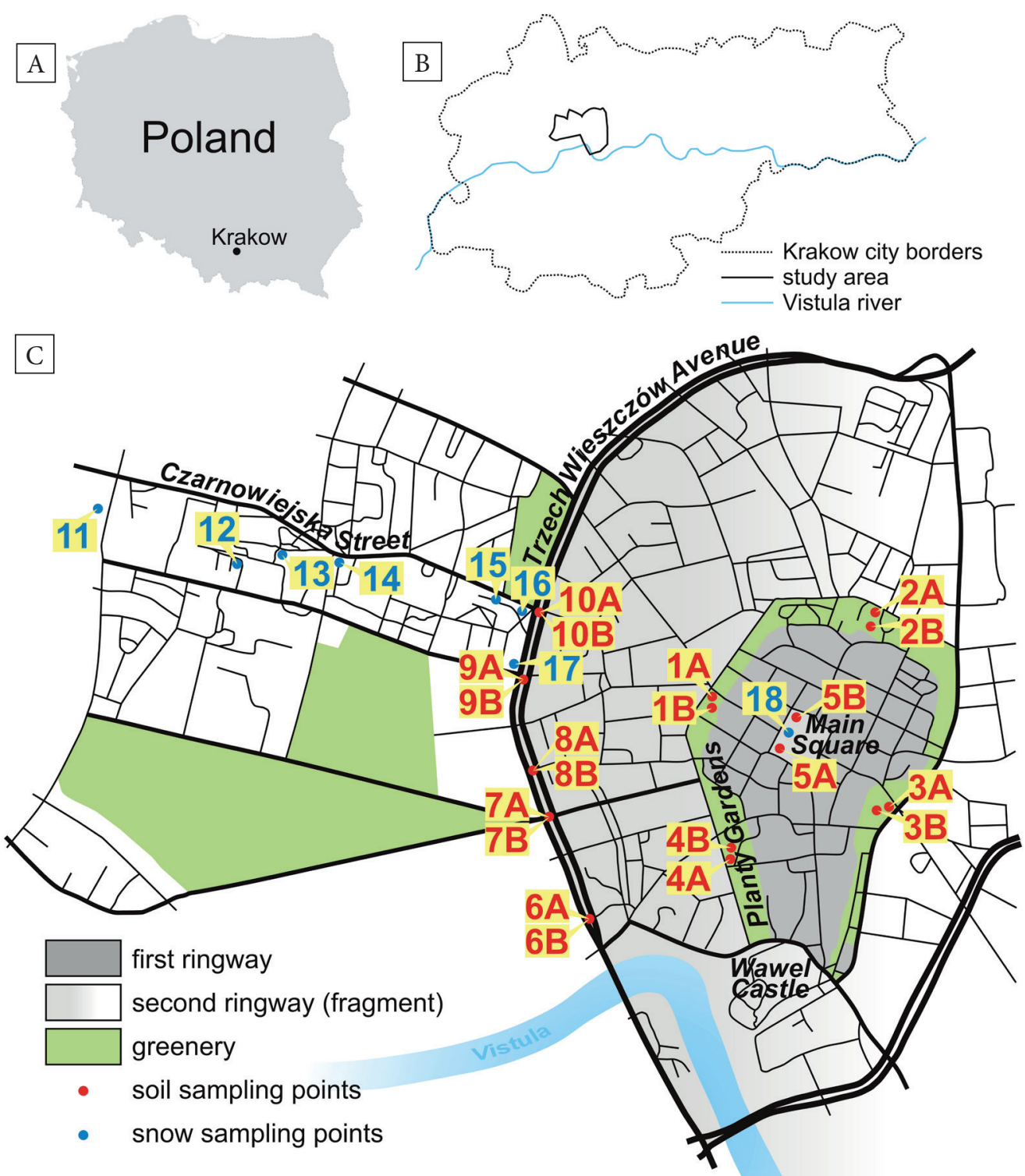

Fig. 1. Study area: A) Krakow's location on a map of Poland; B) study area on the Krakow city map; C) detailed study area and sampling points 


\section{RESULTS AND DISCUSSION}

The value of the reaction for the studied soils was between 7.3 and 8.2 (Tab. 1), which is quite typical for the limestone soils (Czerniawska-Kusza et al. 2004) which are characteristic of the Krakow area. In addition, urban soils, regardless of the degree of their degradation, exhibit a neutral or slightly alkaline reaction, which is conditioned by many factors (Mao et al. 2014), and the obtained results slightly exceeded the background values for the Krakow area, which are between 6.7 and 8.0 (Lis \& Pasieczna 1995). Moreover, the soils of Planty Gardens, which stem from the demolition of the fortifications of medieval Krakow at the beginning of the $19^{\text {th }}$ century, are characterized by a high percentage of construction debris and the related increased carbonates content, which results in a slightly alkaline reaction of these soils (Komornicki 1986). The average carbonate content for the Planty Gardens was $30.4 \mathrm{~g} / \mathrm{kg}$ (November) and $33.3 \mathrm{~g} / \mathrm{kg}$ (February) (Tab. 1), which is within the range of concentration values recorded in the course of a previous study (Komornicki \& Oleksynowa 1989), amounting to $23-40 \mathrm{~g} / \mathrm{kg}$. However, it should be noted that from a long-term perspective, the $\mathrm{pH}$ of soil in the Planty Gardens has been on the rise. According to Komornicki (1986), the $\mathrm{pH}$ of the surface soil samples $(0-20 \mathrm{~cm})$ was between 7.1 and 7.5, whereas in the course of the current study - between 7.6 and 8.2 (November) and between 7.5 and 8.2 (February).

Table 1

Results obtained for soil samples taken from examined areas prior de-icing and after de-icing seasons

\begin{tabular}{|c|c|c|c|c|c|c|c|c|c|}
\hline & & \multicolumn{2}{|c|}{$\mathrm{pH}$} & \multicolumn{2}{|c|}{$\begin{array}{c}\text { Conductivity } \\
{[\mu \mathrm{S} / \mathrm{cm}]}\end{array}$} & \multicolumn{2}{|c|}{$\begin{array}{c}\text { Chlorides } \\
{[\mathrm{mg} / \mathrm{kg}]}\end{array}$} & \multicolumn{2}{|c|}{$\begin{array}{c}\text { Carbonates } \\
{[\mathrm{g} / \mathrm{kg}]}\end{array}$} \\
\hline & & $\begin{array}{c}\text { prior } \\
\text { de-icing } \\
\text { season }\end{array}$ & $\begin{array}{c}\text { after } \\
\text { de-icing } \\
\text { season }\end{array}$ & $\begin{array}{c}\text { prior } \\
\text { de-icing } \\
\text { season }\end{array}$ & $\begin{array}{c}\text { after } \\
\text { de-icing } \\
\text { season }\end{array}$ & $\begin{array}{c}\text { prior } \\
\text { de-icing } \\
\text { season }\end{array}$ & $\begin{array}{c}\text { after } \\
\text { de-icing } \\
\text { season }\end{array}$ & $\begin{array}{c}\text { prior } \\
\text { de-icing } \\
\text { season }\end{array}$ & $\begin{array}{c}\text { after } \\
\text { de-icing } \\
\text { season }\end{array}$ \\
\hline \multirow{9}{*}{$\begin{array}{l}\text { Planty } \\
\text { Gardens }\end{array}$} & $1 \mathrm{~A}(1 \mathrm{~m})$ & 7.6 & 8.2 & 248.0 & 134.5 & 6.9 & 48.5 & 23.3 & 33.2 \\
\hline & $1 \mathrm{~B}(25 \mathrm{~m})$ & 7.7 & 7.5 & 174.2 & 194.6 & 34.6 & 27.7 & nd & nd \\
\hline & $2 \mathrm{~A}(1 \mathrm{~m})$ & 8.2 & 7.7 & 117.2 & 119.6 & 20.8 & 27.7 & 34.3 & 9.8 \\
\hline & $2 \mathrm{~B}(25 \mathrm{~m})$ & 7.7 & 7.9 & 134.4 & 118.4 & 20.9 & 27.7 & nd & nd \\
\hline & $3 \mathrm{~A}(1 \mathrm{~m})$ & 7.8 & 8.0 & 200.0 & 137.8 & 48.5 & 48.5 & 55.2 & 72.6 \\
\hline & $3 \mathrm{~B}(25 \mathrm{~m})$ & 7.8 & 7.8 & 146.5 & 137.8 & nd & 6.9 & nd & nd \\
\hline & $4 \mathrm{~A}(1 \mathrm{~m})$ & 7.9 & 8.1 & 114.5 & 128.6 & 48.5 & 131.5 & nd & nd \\
\hline & $4 \mathrm{~B}(25 \mathrm{~m})$ & 7.7 & 7.8 & 123.2 & 99.7 & 13.9 & 41.5 & 8.9 & 17.4 \\
\hline & Mean & 7.8 & 7.9 & 157.3 & 133.9 & 27.7 & 45.0 & 30.4 & 33.3 \\
\hline \multirow{3}{*}{$\begin{array}{l}\text { Main } \\
\text { Square }^{1}\end{array}$} & $5 \mathrm{~A}$ & 7.6 & 7.8 & 172.6 & 270.0 & 27.9 & 214.6 & nd & nd \\
\hline & $5 \mathrm{~B}$ & 7.3 & 7.7 & 528.0 & 320.0 & 188.4 & 200.8 & 2.4 & 3.3 \\
\hline & Mean & 7.5 & 7.7 & 350.3 & 295.0 & 108.1 & 207.7 & - & - \\
\hline \multirow{11}{*}{$\begin{array}{l}\text { Trzech } \\
\text { Wieszczów } \\
\text { Avenue }^{2}\end{array}$} & $6 \mathrm{~A}(5 \mathrm{~m})$ & 7.6 & 7.7 & 107.7 & 136.6 & 27.8 & 76.1 & nd & nd \\
\hline & $6 \mathrm{~B}(5 \mathrm{~m})$ & 7.5 & 7.5 & 105.1 & 115.3 & 48.6 & 83.0 & 4.7 & 6.8 \\
\hline & $7 \mathrm{~A}(1 \mathrm{~m})$ & 8.0 & 8.2 & 139.5 & 136.7 & 41.7 & 83.0 & 15.0 & 28.0 \\
\hline & $7 \mathrm{~B}(1 \mathrm{~m})$ & 7.8 & 8.1 & 94.5 & 238.0 & 21.0 & 221.2 & nd & nd \\
\hline & $8 \mathrm{~A}(1 \mathrm{~m})$ & 7.8 & 8.2 & 133.7 & 102.0 & 21.0 & 62.2 & 21.5 & 20.0 \\
\hline & $8 \mathrm{~B}(1 \mathrm{~m})$ & 7.9 & 8.1 & 142.5 & 249.0 & 34.8 & 235.1 & nd & nd \\
\hline & 9A $(1 \mathrm{~m})$ & 7.9 & 8.1 & 129.9 & 93.0 & 21.0 & 131.4 & nd & nd \\
\hline & 9B $(1 \mathrm{~m})$ & 7.7 & 8.1 & 103.8 & 140.6 & 27.8 & 48.4 & 8.2 & 11.0 \\
\hline & $10 \mathrm{~A}(1 \mathrm{~m})$ & 7.8 & 8.0 & 134.6 & 112.5 & 52.1 & 615.3 & nd & nd \\
\hline & 10B $(1 \mathrm{~m})$ & 7.8 & 8.1 & 92.9 & 217.0 & 21.0 & 345.7 & 8.4 & 10.7 \\
\hline & Mean & 7.8 & 8.0 & 118.4 & 154.1 & 31.7 & 190.1 & 11.6 & 15.3 \\
\hline
\end{tabular}

nd - not determined. 
An increase in the $\mathrm{pH}$ values was observed after the winter season, however, it was more visible in the case of soil samples collected in the area of the Trzech Wieszczów Avenue, whereas in the area of the Planty Gardens the average $\mathrm{pH}$ during both seasons was more similar, and in the case of two samples (1B and $2 \mathrm{~A})$, the $\mathrm{pH}$ values even dropped after the winter season. In the case of sample $2 \mathrm{~A}$ it was most probably related to the higher concentration of carbonates recorded prior de-icing season. The concentrations of carbonates in the soil samples collected from the green belt in the Trzech Wieszczów Avenue were lower than in the case of those collected from the Planty Gardens, however, the mean $\mathrm{pH}$ of these two areas was similar (Tab. 1). The increase in $\mathrm{pH}$ also results from the ingress of alkaline dusts generated by combustion engine-powered vehicles and road abrasion (Kocher et al. 2005, Kicińska 2016), which is especially significant in case of the Trzech Wieszczów Avenue, influencing the elevated $\mathrm{pH}$ values of this area.

In the area of the Trzech Wieszczów Avenue a slight increase in the conductivity values was observed after the winter season, whereas in the Planty Gardens area this parameter did not vary significantly during both seasons, and even in February (after de-icing season) a slight decrease was observed (Tab. 1). This may be the result of leaching of salt deep inside the soil profile, as a result of higher soil humidity after snowmelt. In general, the observed conductivity was not high, qualifying the studied soils as unsalted. Similar observations for the conductivity of Krakow's soils were obtained by Jakubiak \& Urbański (2015). It is assumed that conductivity not higher than $500 \mu \mathrm{S} / \mathrm{cm}(50 \mathrm{mS} / \mathrm{m})$ is not harmful to vegetation, in the range of $500-1,000 \mu \mathrm{S} / \mathrm{cm}(50-100 \mathrm{mS} / \mathrm{m})$ minor impact on extremely sensitive species can be observed, in the range of $1,000-2,000 \mu \mathrm{S} / \mathrm{cm}(100-200 \mathrm{mS} / \mathrm{m})$ conductivity is harmful for many plant species during the drought period, and over $2,000 \mu \mathrm{S} / \mathrm{cm}$ $(200 \mathrm{mS} / \mathrm{m})$ toxic effect for almost all plant species can be observed (Lech et al. 2016). For the analysed area, only one sample's conductivity exceeded the value of $500 \mu \mathrm{S} / \mathrm{cm}$, and this sample (5B) was collected from the Main Square prior to the de-icing season. Its high conductivity level was probably one of the reasons for the dieback of the tree that was growing there.
The concentration levels of chlorides were markedly higher after the winter, and this increase was particularity visible in the area of the Trzech Wieszczów Avenue. This is unsurprising because this is a very busy street with great significance for the city's traffic, and thus it is subjected to the first national standard for winter road maintenance. Similar observations were made by other researchers (Czerniawska-Kusza et al. 2004, Gałuszka et al. 2011, Jakubiak \& Urbański 2015). The highest concentration levels were defined in samples $10 \mathrm{~A}$ and $10 \mathrm{~B}$, collected in February in the area of a very busy intersection (the Trzech Wieszczów Avenue and Czarnowiejska Street) (Fig. 1, Tab. 1). The concentration of chlorides in the area of the Trzech Wieszczów Avenue after the winter period was on average 6 times higher than in the autumn, however, these concentration levels were still not very high. In the opinion of Sitarski (2008), the natural content of chlorides in soil should not exceed $10 \mathrm{mg} / \mathrm{kg}$, whereas soils chemically processed as a result of a higher salinity, include soils with chlorides concentration exceeding $50 \mathrm{mg} / \mathrm{kg}$. The concentration of chlorides at the level of $50-150 \mathrm{mg} / \mathrm{kg}$ indicates slightly saline soils, $150-300 \mathrm{mg} / \mathrm{kg}$ - medium saline soils and $300-600 \mathrm{mg} / \mathrm{kg}$ - highly saline soils, whereas above $600 \mathrm{mg} / \mathrm{kg}$ the conditions for the growth of plants, especially trees and shrubs, are severely hindered. Therefore, it could be assumed that a salinity level that is safe for vegetation is below $300 \mathrm{mg} / \mathrm{kg}$, and for very sensitive plants below $150 \mathrm{mg} / \mathrm{kg}$. Only two of the studied samples (10A and 10B) exceeded the limit value of $300 \mathrm{mg}$ of chlorides per $\mathrm{kg}$, and sample $10 \mathrm{~A}$ exceeded the $600 \mathrm{mg} / \mathrm{kg}$ threshold as well. Both samples were collected after the winter season. However, in general it could be stated that salinity, measured as the concentration of chloride ions, did not pose a threat to the soil environment. This is mainly the result of the fact that winter seasons in Europe have become increasingly mild and the analysed season was one of the warmest and driest in recent years. The snow cover was present for only about 30 days (between January and February), and the average temperatures were above zero. In consequence, three times fewer de-icing chemicals were used on average than in the previous season, as indicated by data provided by the Municipal Cleaning 
Company (MPO) in Krakow. Similar conclusions were drawn by Jakubiak \& Urbański (2015).

Higher salinity of soil, even temporary, can be one of the reasons for the necrosis of vegetation (Munck et al. 2010) observed in the area of Krakow city. Every year, the Krakow City Roads Administration (ZDMK) plants approx. 1,300-2,500 trees and 7,500-15,000 shrubs. Approx. 3,000 trees and 3,000 shrubs are removed each year, but it is not known how much of this is done because of withering, since in most cases cutting down is related to investments and the development of municipal infrastructure. The problem of the impoverishment of plants, however, is clearly visible on the Main Square, where newly planted trees often need to be replaced due to necrosis. In case of the Main Square soil samples (5A and 5B), disturbingly high values of conductivity and chlorides were observed (Tab. 1), despite a ban on the use of salt in this area. The higher salinity of these samples might also be related to the permeating of soil solutions as a result of soil drought. However, taking into consideration the results recorded for snow samples (Tab. 2), particular attention should be paid to sample 18 taken from the Main Square. For this sample, the highest concentration of chlorides $(486.0 \mathrm{mg} / \mathrm{L})$ was established, while their concentration values for samples collected near the busy Czarnowiejska Street did not exceed $20.6 \mathrm{mg} / \mathrm{L}$. Sample 18 was also characterized by higher $\mathrm{pH}$ and conductivity values, although the differences here were not that dramatic. The chloride concentrations in the snow samples, however, did not exceed the allowable value $(1,000 \mathrm{mg} / \mathrm{L})$, specified by the regulations on conditions to be met when introducing sewage into the waters or into the ground, and on substances particularly harmful to the aquatic environment (Dz.U. $2006 \mathrm{nr}$ 137, poz. 984). Taking into consideration also regulations on the quality of water intended for human consumption (Dz.U. 2017 poz. 2294) and on the methods of classification of the state of consistent surface water bodies and environmental quality standards for priority substances (Dz.U. 2016 poz. 1187), it should be stated that the chloride concentration values measured in the collected snow samples did not pose a threat to the water and soil environment, except for sample 18 taken from the Main Square, where, as has been mentioned before, the use of chlorides is strictly forbidden. Therefore, sample 18 could be expected to be a reference but instead it turned out into an anomalous one. It may not be representative for the whole water-soil environment of the Main Square, but the results obtained are worrisome and it is possible that forbidden de-icing chemicals may be being used illegally in this area. Chlorides and other pollutants may also be transported by pedestrians and animals or carried together with surface drainage, but this is less likely. In general, the Main Square territory is already highly disturbed because its surface is almost completely covered by a pavement and the results obtained for samples collected in this area show a poor condition of the local water-soil environment. The accumulation of stress factors results in the rapid necrosis of trees growing in the Main Square area and necessitates new plantings.

Table 2

Results obtained for snow samples taken from two examined areas

\begin{tabular}{|l|l|c|c|c|}
\cline { 3 - 5 } \multicolumn{2}{c|}{} & $\mathbf{p H}$ & $\begin{array}{c}\text { Conductivity } \\
{[\boldsymbol{\mu S} / \mathbf{c m}]}\end{array}$ & $\begin{array}{c}\text { Chlorides } \\
{[\mathbf{m g} / \mathbf{L}]}\end{array}$ \\
\hline \multirow{4}{*}{$\begin{array}{l}\text { Czarno- } \\
\text { wiejska } \\
\text { Street }^{1}\end{array}$} & 11 & 7.6 & 157.5 & 4.7 \\
\cline { 2 - 5 } & 12 & 7.4 & 60.5 & 3.3 \\
\cline { 2 - 5 } & 13 & 7.3 & 104.7 & 17.6 \\
\cline { 2 - 5 } & 15 & 7.5 & 69.7 & 9.0 \\
\cline { 2 - 5 } & 16 & 7.1 & 116.5 & 20.6 \\
\cline { 2 - 5 } & 17 & 7.4 & 39.1 & 10.0 \\
\cline { 2 - 5 } & Mean & 7.3 & 91.8 & 4.3 \\
\hline $\begin{array}{l}\text { Main } \\
\text { Square }^{2}\end{array}$ & 18 & 7.7 & 164.6 & 9.9 \\
\hline
\end{tabular}

${ }^{1}$ Czarnowiejska Street is located beyond the second ringway (Fig. 1);

${ }^{2}$ Main Square is located within the first ringway (Fig. 1).

The impact of the distance from the road edge on the studied physical and chemical parameters of soils was also analysed in the course of the present study, and it was found to be significant. As it is hard to consider the solely spatial changes of the examined parameters, a combined spatial and temporal analysis has been done. The only parameter which is always higher (or about the same) in samples taken closer to the road edge, when compared with samples taken further from the road edge, regardless of the season, is $\mathrm{pH}$ (Tab. 3). In the case of other parameters there are some 
exceptions: in the area of the Planty Gardens, conductivity is lower closer to the road edge after de-icing season, and in the Trzech Wieszczów Avenue, chlorides are lower closer to the street lane prior de-icing season. Nevertheless, in general, the average values of all three considered parameters are higher closer to the road. The temporary increase of chlorides and $\mathrm{pH}$ after the de-icing season is visible both for samples taken from the area of Planty Gardens and Trzech Wieszczów Avenue, especially near to the road edge, but it is more visible for the samples from the Trzech Wieszczów Avenue, where a temporary increase of conductivity is also observed (Tab. 3).

The studies have shown that $20-63 \%$ of road salt is transported through the air and is deposited at a distance of 2-40 $\mathrm{m}$ from the road (Blomqvist \& Johansson 1999), more than $90 \%$ of salt is deposited at the distance of $15-20 \mathrm{~m}$ from the road edge (Hofman et al. 2012), chloride concentrations decline on average ten times at a distance of $10 \mathrm{~m}$ from the road edge (Findlay \& Kelly 2011) and the maximum distance over which salt is transported is proportional to the speed of vehicles on the roads (McBean \& Al-Nassri 1987). The presented interdependencies are clearly visible for samples collected from the Planty Gardens at a distance of approx. $25 \mathrm{~m}$ from the street pavement edge, where the parameters are relatively stable, and conductivity after the winter season even decreases (Tab. 3). The salinity of soil decreases faster in areas with a high number of trees, in comparison to areas which are scarcely covered with trees, which results from the salt being accumulated by the plants. Summing up, salinity and $\mathrm{pH}$ values are generally lower in parks than in strips located near the roads (Bach \& Pawłowska 2006, Amundsen et al. 2010).

The most significant source of salinity of urban soils is undoubtedly the salt use for road de-icing, but other sources should not be neglected, and these include: mining and salt and sulphur processing, combined heat and power plants burning saline and sulphated coal, bottom waters of metalliferous ore and bituminous coal mines, car transportation, municipal management, hardening of roads and squares using slag, leachates from industrial waste landfills or heaps (e.g. from the closed Sodium Solvay Factory in Krakow), excessive fertilisation of urban green areas or gypsum ingress into soil (Adamiec et al. 2013, Jakubiak \& Urbański 2015, Vargas et al. 2018).

\section{Table 3}

Comparison of averaged results obtained for soil samples taken from the Trzech Wieszczów Avenue and the Planty Gardens, close to and far from the road edge

\begin{tabular}{|c|c|c|c|c|c|}
\hline & & & \multirow{3}{*}{$\begin{array}{c}\mathbf{p H} \\
7.9\end{array}$} & \multirow{3}{*}{$\begin{array}{c}\text { Conductivity }[\mu \mathrm{S} / \mathrm{cm}] \\
169.9\end{array}$} & \multirow{3}{*}{$\frac{\text { Chlorides }[\mathrm{mg} / \mathbf{k g}]}{31.2}$} \\
\hline & & & & & \\
\hline \multirow{4}{*}{$\begin{array}{l}\text { Planty } \\
\text { Gardens }\end{array}$} & \multirow{2}{*}{$\begin{array}{l}\text { close to the road } \\
\text { edge }(1 \mathrm{~m})\end{array}$} & prior de-icing season & & & \\
\hline & & after de-icing season & 8.0 & 130.1 & 64.0 \\
\hline & \multirow{2}{*}{$\begin{array}{l}\text { far from the road } \\
\text { edge }(25 \mathrm{~m})\end{array}$} & prior de-icing season & 7.7 & 144.6 & 23.1 \\
\hline & & after de-icing season & 7.7 & 137.6 & 26.0 \\
\hline \multirow{4}{*}{$\begin{array}{l}\text { Trzech } \\
\text { Wieszczów } \\
\text { Avenue }^{2}\end{array}$} & \multirow{2}{*}{$\begin{array}{l}\text { close to the road } \\
\text { edge }(1 \mathrm{~m})\end{array}$} & prior de-icing season & 7.8 & 121.4 & 30.0 \\
\hline & & after de-icing season & 8.1 & 161.1 & 217.8 \\
\hline & \multirow{2}{*}{$\begin{array}{l}\text { far from the road } \\
\text { edge }(5 \mathrm{~m})\end{array}$} & prior de-icing season & 7.5 & 106.4 & 38.2 \\
\hline & & after de-icing season & 7.6 & 126.0 & 79.5 \\
\hline
\end{tabular}

${ }^{1}$ Planty Gardens are located within the first ringway (Fig. 1);

${ }^{2}$ Trzech Wieszczów Avenue is a part of the second ringway (Fig. 1).

\section{SUMMARY AND CONSIDERATIONS}

De-icing of roads in the winter season is necessary and required in view of the safety of public roads. The applied agent is most commonly selected according to its price and availability, and unfortunately the environmental aspects are taken into consideration to a lesser extent. Using salt to de-ice streets may be inexpensive but, apart from environmental damage, the actual costs related to the application of this agent should also include the following costs: maintenance and repair 
of corroded metal elements of road infrastructure or vehicles, reclamation of saline soils or new planting of decayed vegetation (Kelly et al. 2008).

The alternative to the harmful use of salt may be to increase the proportion of the roughness enhancing agent, i.e. sand, although it is easily blown away from roads and must be removed after the winter season ends. It would be advisable to implement devices that would calibrate the amount of applied salt, because very often it is used in much larger amounts than is necessary. Supplementing $\mathrm{NaCl}$ with organic materials, like beet or brewery wastes, increases the adhesion of salt to the road, decreasing rates of its application in that way. The use of safer but unfortunately often more expensive agents should also be considered, especially in particularly valuable areas. This could be, for example, calcium chloride with the addition of other salts or modifiers (e.g. ammonium phosphate) acting as corrosion inhibitors and $\mathrm{pH}$ regulators. Saturation of the soil solution with calcium or magnesium cations facilitates better maintenance of a neutral $\mathrm{pH}$, because these ions are more strongly absorbed than $\mathrm{Na}^{+}$and do not affect the dissociation of water. On the other hand, apart from the higher costs of alternative chemicals, their environmental impact is often not adequately studied, which does not guarantee the safety of their usage (Findlay \& Kelly 2011, Gałuszka et al. 2011).

Heavy traffic and high vehicles speeds cause the slush to be splashed over great distances, thus, perhaps in the winter season additional speed limits should be introduced. A well-designed system of leachate collection from roads is also necessary. Various barriers and small walls can be used to protect vegetation located near roads, however, their effectiveness is limited and may contribute to physiological drought. In areas with intense traffic, trees should be planted away from the street pavement and more resistant species should be selected. Additionally, the windrows of polluted snow should not be placed around trees. Irrigation procedures and soil fertilization, as well as appropriate vegetation care, are recommended (Hootman et al. 1994, Findlay \& Kelly 2011).

Although in general a deterioration of the examined parameters was observed after the winter season, results for most samples did not pose a serious threat to the water-soil environment in
Krakow. We assume that, due to increasingly mild winter seasons, the salinity increase of soils connected with winter road maintenance should not be a very serious environmental problem in the future, especially if the above mentioned remedies are implemented. However, the state of the Main Square environment is concerning, and improving soil treatment in this area is suggested.

This work was supported by the project of the Faculty of Geology, Geophysics and Environmental Protection at the AGH University of Science and Technology (no. 16.16.140.315).

\section{REFERENCES}

Adamiec E., Wieszała R., Strzebońska M. \& Jarosz-Krzemińska E., 2013. An attempt to identify traffic related elements in snow. Geology, Geophysics \& Environment, 39, 4, 317-329.

Amundsen C.E., Håland S., French H., Roseth R. \& Kitterød N.-O., 2010. Salt SMART. Environmental damages caused by road salt - a literature review. Norwegian Public Roads Administration Directorate of Public Roads Technology Department, Oslo.

Bach A. \& Pawłowska B., 2006. Effect of sodium chloride salinity and $\mathrm{pH}$ of soil on ornamental urban trees in Kraków with regard to nature conservations in cities. Ecological Chemistry and Engineering, 13, 455-461.

Bäckström M., Karlsson S., Bäckman J., Folkeson L. \& Lind B., 2004. Mobilisation of heavy metals by deicing salts in a roadside environment. Water Research, 38, 3, 720-732.

Blomqvist G. \& Johansson E.-L., 1999. Airborne spreading and deposition of de-icing salt - a case study. Science of the Total Environment, 235, 1-3, 161-168.

Czerniawska-Kusza I., Kusza G. \& Dużyński M., 2004. Effect of Deicing Salts on Urban Soils and Health Status of Roadside Trees in the Opole Region. Environmental Toxicology, 19, 296-304.

Černohlávková J., Hofman J., Bartoš T., Sáňka M. \& Anděl P., 2008. Effects of road deicing salt on soil microorganisms. Plant, Soil and Environment, 54, 11, 479-485.

Ćwiąkała M., Kołodziejczyk U. \& Rafalski L., 2012. The influence of selected chemical compounds used in winter road maintenance on the active capillarity of soils. Journal of Soils and Sediments, 13, 1, 64-71.

Dailey K.R., Welch K.A. \& Lyons B.W., 2014. Evaluating the influence of road salt on water quality of Ohio rivers over time. Applied Geochemistry, 47, 25-35.

Dz.U. 2005 nr 230, poz. 1960. Rozporządzenie Ministra Środowiska z dnia 27 października 2005 r. w sprawie rodzajów i warunków stosowania środków, jakie moga być używane na drogach publicznych oraz ulicach i placach.

Dz.U. 2006 nr 137, poz. 984. Rozporządzenie Ministra Środowiska z dnia 24 lipca 2006 r. w sprawie warunków, jakie należy spetnić przy wprowadzaniu ścieków do wód lub do ziemi, oraz $w$ sprawie substancji szczególnie szkodliwych dla środowiska wodnego. 
Dz.U. 2016 poz. 1187. Rozporządzenie Ministra Środowiska $z$ dnia 21 lipca $2016 r$. w sprawie sposobu klasyfikacji stanu jednolitych części wód powierzchniowych oraz środowiskowych norm jakości dla substancji priorytetowych.

Dz.U. 2017 poz. 2294. Rozporzadzenie Ministra Zdrowia $z$ dnia 7 grudnia 2017 r. w sprawie jakości wody przeznaczonej do spożycia przez ludzi.

Findlay S.E.G. \& Kelly V.R., 2011. Emerging indirect and long-term road salt effects on ecosystems. Annals of the New York Academy of Sciences, 1223, 58-68.

Francois L.E. \& Maas E.V., 1999. Crop Response and Management of Salt-Affected Soils. [in:] Pessarakli M. (ed.), Handbook of Plant and Crop Stress, Marcel Dekker, New York - Basel, 169-201.

Gałuszka A., Migaszewski Z.M., Podlaski R., Dołęgowska S. \& Michalik A., 2011. The influence of chloride deicers on mineral nutrition and the health status of roadside trees in the city of Kielce, Poland. Environmental Monitoring and Assessment, 176, 1-4, 451-464.

Godwin K.S., Hafner S.D. \& Buff M.F., 2003. Long-term trends in sodium and chloride in the Mohawk River, New York: The effect of fifty years of road-salt application. Environmental Pollution, 124, 273-281.

Green S.M. \& Cresser M.S., 2008. Nitrogen cycle disruption through the application of de-icing salts on upland highways. Water, Air and Soil Pollution, 188, 139-153.

Green S.M., Machin R. \& Cresser M.S., 2008. Effect of longterm changes in soil chemistry induced by road salt applications on N-transformations in roadside soils. Environmental Pollution, 152, 20-31.

Hofman J., Trávníčková E. \& Anděl P., 2012. Road salts effects on soil chemical and microbial properties at grassland and forest site in protected natural areas. Plant, Soil and Environment, 58, 6, 282-288.

Hootman R.G., Kelsey P.D., Reid R. \& von der Heide-Spravka K., 1994. Factors affecting accumulation of deicing salt in soils around trees. Journal of Arboriculture, 20, 3, 196-201.

ISO 9297:1989. Water quality - Determination of chloride Silver nitrate titration with chromate indicator (Mohr's method). International Organization for Standardization.

ISO 11265:1994. Soil quality - Determination of the specific electrical conductivity. International Organization for Standardization.

ISO 10693:1995. Soil quality - Determination of carbonate content - Volumetric method. International Organization for Standardization.

ISO 10390:2005. Soil quality - Determination of pH. International Organization for Standardization.

ISO 11464:2006. Soil quality - Pretreatment of samples for physico-chemical analysis. International Organization for Standardization.

ISO 23909:2008. Soil quality - Preparation of laboratory samples from large samples. International Organization for Standardization.

ISO 18400-104:2018. Soil quality - Sampling - Part 104: Strategies. International Organization for Standardization.

Jakubiak M. \& Urbański K., 2015. Impact and range assessment of anthropogenic salinity in the vicinity of communication routes on the example of national road no. 79 in Kraków. Logistyka, 4, 8997-9004.
Kelly V.R., Lovett G.M., Weathers K.C., Findlay S.E.G., Strayer D.L., Burns D.J. \& Likens G.E., 2008. Long-Term Sodium Chloride Retention in a Rural Watershed: Legacy Effects of Road Salt on Streamwater Concentration. Environmental Science \& Technology, 42, 410-415.

Kelly V.R., Findlay S.E.G., Schlesinger W.H., Menking K. \& Chatrchyan A.M., 2010. Road Salt, Moving Toward the Solution. Special Report, Cary Institute of Ecosystem Studies.

Kelting D.L., Laxson C.L. \& Yerger E.C., 2012. Regional analysis of the effect of paved roads on sodium and chloride in lakes. Water Research, 46, 2749-2758.

Kicińska A., 2016. Assessment of the road traffic impact on accumulation of selected elements in soils developed on Krynica and Bystrica subunit (Magura Nappe, Polish Outer Carpathians). Carpathian Journal of Earth and Environmental Sciences, 11, 1, 245-254.

Kocher B., Wessolek G. \& Stoffregen H., 2005. Water and heavy metal transport in roadside soils. Pedosphere, 15, 746-753.

Kołodziejczyk U. \& Ćwiąkała M., 2009. Evaluation of the efficiency of use of aggregates and chemical compounds for winter road maintenance. Civil and Environmental Engineering Reports, 3, 67-76.

Komornicki T., 1986. Gleby Plant krakowskich. Roczniki Gleboznawcze, 37, 4, 187-200.

Komornicki T. \& Oleksynowa K., 1989. Zawartość ołowiu i cynku w glebach Plant krakowskich. Roczniki Gleboznawcze, 40, 2, 213-226.

Lech M., Fronczyk J., Radziemska M., Sieczka A., Garbulewski K., Koda E. \& Lechowicz Z., 2016. Monitoring of total dissolved solids on agricultural lands using electrical conductivity measurements. Applied Ecology and Environmental Research, 14, 4, 285-295.

Lis J. \& Pasieczna A., 1995. Atlas geochemiczny Krakowa i okolic: 1:100 000. Wydawnictwo Kartograficzne Polskiej Agencji Ekologicznej, Warszawa.

Löfgren S., 2001. The Chemical Effects of Deicing Salt on Soil and Stream Water of Five Catchments in Southeast Sweden. Water, Air, and Soil Pollution, 130, 1-4, 863-868.

Lumis G.P., Hofstra G. \& Hall R., 1976. Roadside woody plant susceptibility to sodium and chloride accumulation during winter and spring. Canadian Journal of Plant Science, 56, 4, 853-859.

Mao Y., Sang S., Liu S. \& Jia J., 2014. Spatial distribution of $\mathrm{pH}$ and organic matter in urban soils and its implications on site-specific land uses in Xuzhou, China. Comptes Rendus Biologies, 337, 5, 332-337.

McBean E. \& Al-Nassri S., 1987. Migration pattern of de-icing salts from roads. Journal of Environmental Management, $25,3,231-238$.

Munck I.A., Bennett C.M., Camilli K.S. \& Nowak R.S., 2010. Long-term impact of de-icing salts on tree health in the Lake Tahoe Basin: Environmental influences and interactions with insects and diseases. Forest Ecology and Management, 260, 1218-1229.

Munns R. \& Termaat A., 1986. Whole-Plant Responses to Salinity. Australian Journal of Plant Physiology, 13, 1, 143-160.

Norrman J., 2000. Slipperiness on roads - an expert system classification. Meteorological Applications, 7, 27-36. 
Novotny V., Muehring D., Zitomer D.H., Smith D.W. \& Facey D., 1998. Cyanide and metal pollution by urban snowmelt: Impact of deicing compounds. Water Science and Technology, 38, 10, 223-230.

Perera N., Gharabaghi B. \& Howard K., 2013. Groundwater chloride response in the Highland Creek watershed due to road salt application: A re-assessment after 20 years. Journal of Hydrology, 479, 159-168.

Provin T. \& Pitt J.L., 2019. Managing Soil Salinity. [on-line:] https://oaktrust.library.tamu.edu/bitstream/handle/1969.1/ 86985/pdf_1397.pdf?sequence=1 [access: 17.04.2019].

Ramarkishana D.M. \& Viraraghavatan T., 2005. Environmental Impact of Chemical Deicers - A Review. Water, Air, and Soil Pollution, 166, 1-4, 49-63.

Sitarski M., 2008. Charakterystyka warunków glebowych i szaty roślinnej w wybranych osiedlach mieszkaniowych Warszawy. Człowiek i Środowisko, 32, 1-2, 19-41.
Siyal A.A., Siyal A.G. \& Abro Z.A., 2002. Salt affected soils their identification and reclamation. Pakistan Journal of Applied Sciences, 2, 5, 537-540.

Thunqvist E.L., 2004. Regional increase of mean chloride concentration in water due to the application of deicing salt. Science of the Total Environment, 325, 29-37.

Turunen M., 1997. Measuring salt and freezing temperature on roads. Meteorological Applications, 4, 11-15.

Vargas R., Pankova E.I., Balyuk S.A., Krasilnikov P.V. \& Khasankhanova G.M. (eds.), 2018. Handbook for saline soil management. Food and Agriculture Organization of the United Nations, Lomonosow Moscow State University.

Yuan B.-C., Li Z.-Z., Liu H., Gao M. \& Zhang Y.-Y., 2007. Microbial biomass and activity in salt affected soils under arid conditions. Applied Soil Ecology, 35, 2, 319-328. 